\title{
Caudoventral hip luxation in a miniature pig
}

\section{Carolina Silveira Braga ${ }^{1}$ Brunna de Souza Barni ${ }^{1}$ Marcele de Souza Muccillo ${ }^{1}$ Emerson Antonio Contesini ${ }^{1}$ Marcelo Meller Alievi ${ }^{{ }^{*}}$}

${ }^{1}$ Faculdade de Veterinária (FAVET), Universidade Federal do Rio Grande do Sul (UFRGS), Av. Bento Gonçalves, 9090, Bairro Agronomia, 91540-000, Porto Alegre, RS, Brasil. E-mail: marcelo.alievi@ufrgs.br. "Corresponding author.

\begin{abstract}
A miniature pig was examined because of left pelvic limb lameness after falling from a short height. Clinical examination and radiographs of the pelvic region revealed a left caudoventral hip luxation. Surgical reduction of luxation was performed on the patient under general anesthesia using a transarticular pinning technique. Postoperative radiographs confirmed that the luxation was reduced, the joint was aligned, and the transarticular pinning was correct. The transarticular pin was removed 21 days after it was surgically inserted. The limb was fully functional in the immediate postoperative period. Nine months after the surgery, the patient could use the limb properly, but mild degenerative joint disease was observed via radiographic follow-up. This technique may be a viable treatment option for the repair of caudoventral hip luxation in miniature pigs.

Key words: Sus scrofa domestica, coxofemoral luxation, transarticular pin.
\end{abstract}

Luxação caudoventral de quadril em um mini-pig

RESUMO: Um mini-pig foi atendido devido à claudicação do membro pélvico esquerdo após pequena queda. O exame clínico e radiografias da região pélvica revelaram uma luxação caudoventral de quadril no lado esquerdo. A redução cirúrgica da luxação foi realizada, com o paciente sob anestesia geral, usando um pino transarticular. As radiografias pós-operatórias confirmaram que a luxação foi reduzida, com alinhamento e fixação transarticular corretos. O pino transarticular foi removido cirurgicamente 21 dias após de ter sido inserido. $O$ membro se tornou totalmente funcional já no periodo pós-operatório imediato. Nove meses após a cirurgia, o paciente utilizava o membro corretamente, porém foi detectada doença articular degenerativa leve através de acompanhamento radiográfico. A técnica empregada foi uma opção viável de tratamento para a reparação da luxação caudoventral de quadril em mini-pig.

Palavras-chave: Sus scrofa domestica, luxação coxofemoral, pino transarticular.

Hip luxation, in which the femoral head is displaced from the acetabulum, is often secondary to trauma in small animals (BASHER, 1986). Caudoventral hip luxation rarely occurs in dogs and cats (ÇETINKAYA \& OLCAY, 2010). Although, the diagnosis can be based on clinical findings, radiographs are essential because treatment is determined according to the type and duration of the luxation and based on the presence of concomitant lesions or degenerative joint disease (MOORES, 2006). Miniature pigs (Sus scrofa domestica) are docile small animals that are widely used in biomedical research (SMITH et al., 2005). Recently, they have risen in popularity as companion animals because their full adult size is similar to that of medium- sized dogs. In this study, we described the treatment of a miniature pig diagnosed with caudoventral hip luxation, taking into consideration the paucity of information on the orthopedic disorders that affect these unconventional pets.

A 5-month-old, $4.8 \mathrm{~kg}$ female miniature pig was admitted to our teaching hospital because of left pelvic limb lameness after falling from a short height 5 days earlier. Clinical examination showed limb abduction with internal rotation of the knee, mild pain, crepitus, limited range of motion during left hip manipulation, and a lack of palpable symmetry on the left side between the ischial tuberosity and the greater trochanter. A blood sample was collected from the auricular 
vein, and the results of a complete blood count and serum biochemical profile were within normal ranges for the species. Ventrodorsal and laterolateral radiographs of the pelvic region were performed on the patient while it was anesthetized with ketamine $\left(6 \mathrm{mg} \mathrm{kg} \mathrm{kg}^{-1} \mathrm{IM}\right)$ and midazolam $\left(0.5 \mathrm{mg} \mathrm{kg}^{-1} \mathrm{IM}\right)$. Results revealed a left caudoventral hip luxation (Figure 1A). While the patient was still under anesthesia, a closed reduction was attempted but was unsuccessful. The patient was then referred for surgery, which was performed 4 days after the diagnosis.

For the surgery, the patient was anesthetized via ketamine $\left(6 \mathrm{mg} \mathrm{kg}^{-1} \mathrm{IM}\right)$ and midazolam $(0.5 \mathrm{mg}$ $\mathrm{kg}^{-1}$ IM) to achieve chemical restraint. Thereafter, an IV catheter was placed in the marginal ear vein. General anesthesia was induced with propofol $(5 \mathrm{mg}$ $\mathrm{kg}^{-1} \mathrm{IV}$ ) and maintained with isoflurane in oxygen that was delivered via a rebreathing system. Lumbosacral epidural anesthesia was accomplished by using morphine $\left(0.1 \mathrm{mg} \mathrm{kg}^{-1}\right)$ and lidocaine $\left(1 \mathrm{mg} \mathrm{kg}^{-1}\right)$. Cefazolin sodium $\left(22 \mathrm{mg} \mathrm{kg}^{-1} \mathrm{IV}\right)$ was administered prior to the surgery.

The patient was positioned in right lateral recumbency, and the surgical site was clipped and prepared for surgery via routine procedures. A craniolateral approach was made to access the hip joint. Acetabulum and femoral head were inspected, and the joint fibrin debris was gently removed, which allowed manual reduction of the luxation. Joint stability was tested by subjecting the joint to its full range of motion. A 2-mm Steinmann pin was inserted through the femoral neck and head with a Jacob's chuck until it reached and then went slightly past the acetabulum. The insertion was confirmed using intraoperative rectal palpation. The pin was folded on the lateral surface and the excess was cut away. A capsulorrhaphy was performed using suture apposition with a simple interrupted pattern and 2-0 nylon. The fascia and subcutaneous tissue were sutured with a simple continuous pattern using 2-0 polyglactin, and the skin was sutured with a simple interrupted pattern using 3-0 nylon. Recovery from anesthesia was uncomplicated. Postoperative analgesia consisted of tramadol (5mg kg-1 q12h SC) and meloxicam $\left(0.2 \mathrm{mg} \mathrm{kg}^{-1} \mathrm{q} 24 \mathrm{~h} \mathrm{SC}\right)$ for three days following the surgery.

Postoperative radiographs confirmed that the luxation was reduced, the joint was aligned, and the transarticular pinning was correct (Figure 1B). The patient's physical activity was restrained using tape hobbles that were removed on postoperative day 10, when the animal could use the limb properly. The transarticular pin was removed 21 days after its insertion with the patient under general anesthesia using the previously described protocol. The limb was fully functional in the immediate postoperative period. Nine months after the surgery, the patient was able to use the limb properly, but mild degenerative joint disease was observed during the radiographic follow-up (Figure 1C).

Caudoventral hip luxation, which in our case report presented no concomitant lesions in the miniature pig, is rare and often associated with

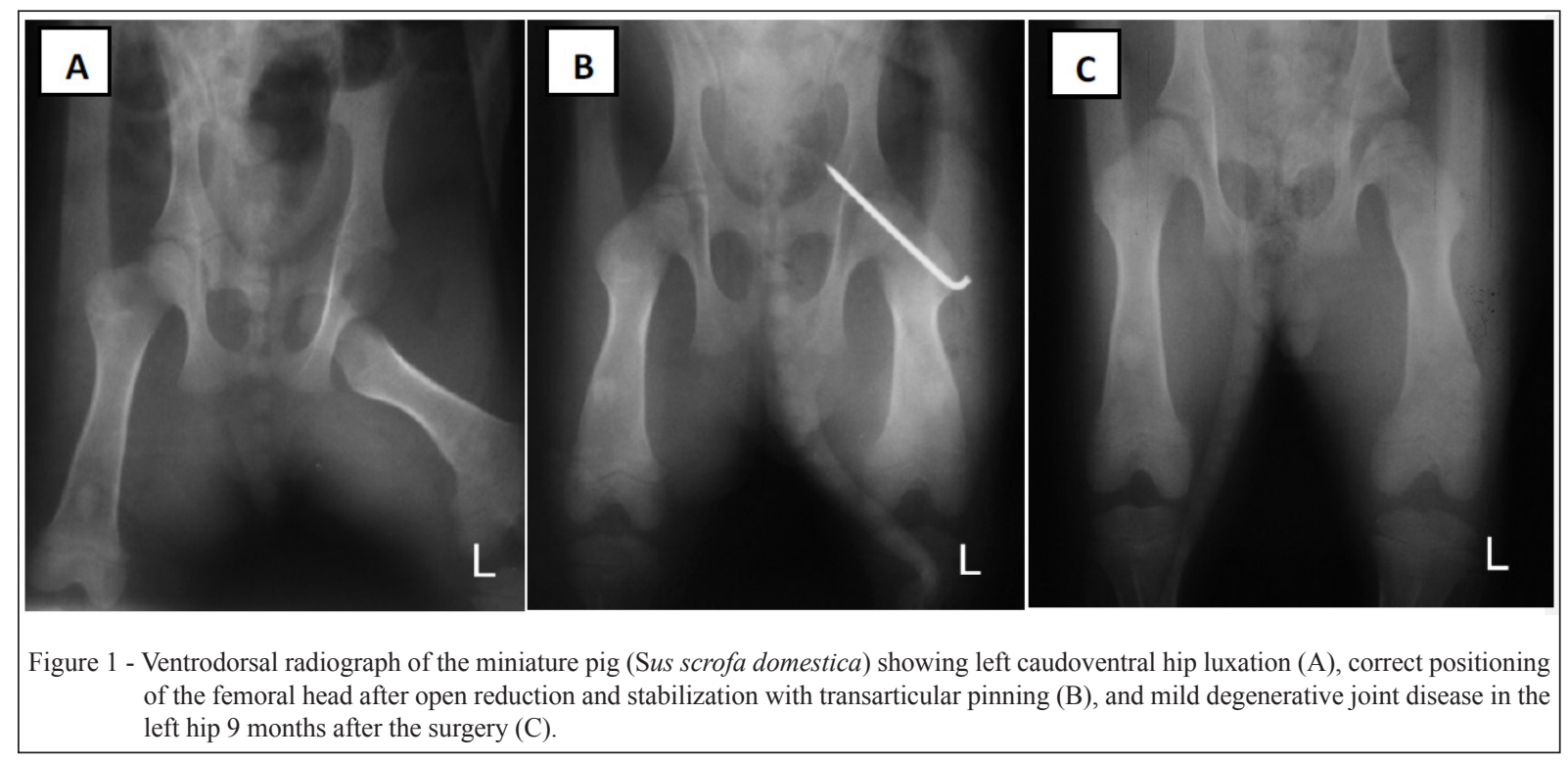

Ciência Rural, v.47, n.7, 2017. 
greater trochanter fracture in dogs (BARBOSA \& SCHOSSLER, 2009). In our patient, clinical examination revealed lameness, abduction of the affected pelvic limb, and internal rotation of the knee, which are symptoms that have been previously described in dogs (VENZIN \& MONTAVON, 2007). Etiology of luxation in this patient was related to a fall and excessive limb abduction and; therefore, differs from the data obtained from small animals with craniodorsal hip luxation, in which motor vehicle accidents were the major cause (MCCARTNEY et al., 2011).

To confirm the diagnosis, the miniature pig was submitted to radiographic imaging of the affected region, which is crucial to rule out other lesions and to select the best therapy option (MOORES, 2006). Clinical manifestations during the 5 days before admission to the hospital most likely prevented the success of a closed reduction, a finding that was also observed in small-sized dogs with this type of luxation. Closed reductions sometimes fail, and surgical treatment then becomes necessary (VENZIN \& MONTAVON, 2007).

The open reduction included a capsulorrhaphy, which is a technique that has already been used in conjunction with other techniques in domestic animals (DEMKO et al., 2006; VENTURINI et al., 2010). Transarticular pinning was successful, even though it is indicated for recurrent luxation or in cases in which more conservative methods cannot be used (BENNETT \& DUFF, 1980); the use of a toggle pin would have been another alternative and has been used successfully in the treatment of caudoventral hip luxations in small animals (ÇETINKAYA \& OLCAY, 2010). The use of tape hobbles in the postoperative period was described in a dog after an open reduction of a caudoventral hip luxation and prevented excessive limb abduction during joint healing (VENZIN \& MONTAVON, 2007). In our case, the transarticular pin was removed after 21 days, which was performed because the method chosen for reduction of the luxation should provide stability for 3 to 4 weeks, allowing the joint capsule to heal (BARBOSA \& SCHOSSLER, 2009).

The degenerative joint disease detected in the miniature pig 9 months after the surgery has also been observed in dogs treated for luxation. However, its etiology has not been completely elucidated; it could be secondary to the initial joint trauma, to reduction-induced trauma, or to the hip stabilization techniques used (VENZIN \& MONTAVON, 2007). A modified transarticular pinning approach for the treatment of hip luxation in dogs also resulted in major post-traumatic degenerative joint disease (MCCARTNEY et al., 2011). The method we used to treat caudoventral hip luxation in this miniature pig was efficient and without recurrence and did not interfere with the patient's quality of life, despite the presence of degenerative joint disease diagnosed 9 months after the surgery.

\section{BIOETHICS AND COMMITTEE APPROVAL}

BIOSECURITY

The authors of the paper entitled "Caudoventral hip luxation in a miniature pig" declare that, as a case report, the procedure that originated the data reported here was not submitted for evaluation by the Ethics Committee of the Universidade Federal do Rio Grande do Sul (UFRGS) because it did not constitute a project, but we are aware of the content of resolutions from the Conselho Nacional de Controle de Experimentação Animal (CONCEA) <http://www.mct.gov.br/upd_blob/0238/238343.pdf $>$ involving animals. As such, the authors take full responsibility for the data presented here and are available for possible queries, if that is required by the competent authorities.

\section{REFERENCES}

BARBOSA, A.L.T; SCHOSSLER, J.E.W. Luxação coxofemoral traumática em cães e gatos: estudo retrospectivo (1997-2006). Ciência Rural, v.39, n.6, p.1823-1829, 2009. Available from: $<$ http://www.scielo.br/scielo.php?script=sci_arttext\&pid $=\mathrm{S} 0103-84782009000600028>$. Accessed: Jun. 23, 2016. doi: $10.1590 / \mathrm{S} 0103-84782009000600028$.

BASHER, A.W. et al. Coxofemoral luxation in dog and cat. Veterinary Surgery, v.15, n.5, p.356-362, 1986. Available from: $<$ http://onlinelibrary.wiley.com/doi/10.1111/j.1532-950X.1986. tb00243.x/epdf>. Accessed: Jun. 23, 2016. doi: 10.1111/j.1532950X.1986.tb00243.x.

BENNETT, D.; DUFF, S.R. Transarticular pinning as a treatment for hip luxation in the dog and cat. Journal of Small Animal Practice, v.21, n.7, p.373-379, 1980. Available from: <http:// onlinelibrary.wiley.com/doi/10.1111/j.1748-5827.1980. tb01264.x/epdf $>$. Accessed: Jun. 23, 2016. doi: 10.1111/j.17485827.1980.tb01264.x

ÇETINKAYA, M.A.; OLCAY, B. Modified knowles toggle pin with monofilament suture material for treatment of two caudoventral hip luxation cases. Veterinary and Comparative Orthopaedics and Traumatology, v.23, n.2, p.114-118, 2010. Available from: <http:// vcot.schattauer.de/en/contents/archiveestandard/issue/1050/ manuscript/12641.html>. Accessed: Jun. 23, 2016. doi: 10.3415/ VCOT-09-03-0027.

DEMKO, J.L. et al. Toggle rod stabilization for treatment of hip joint luxation in dogs: 62 cases (2000-2005). Journal of the American Veterinary Medical Association, v.229, n.6, p.984989, 2006. Available from: <http://avmajournals.avma.org/doi/ full/10.2460/javma.229.6.984>. Accessed: Jun. 23, 2016. doi: 10.2460/javma.229.6.984

MCCARTNEY, W. et al. Treatment of 70 dogs with traumatic hip luxation using a modified transarticular pinning technique. Veterinary Record, v.168, n.13, p.355, 2011. Available from: 
$<$ http://veterinaryrecord.bmj.com/content/early/2011/03/02/ vr.c6417>. Accessed: Jun. 23, 2016. doi: 10.1136/vr.c6417.

MOORES, A. Decision making in the management of hip luxations in dogs and cats. In Practice, v.28, n.10, p.570-576, 2006. Available from: <http://inpractice.bmj.com/content/28/10/570. full.pdf + html $>$. Accessed: June 23, 2016. doi: 10.1136/ inpract.28.10.570.

SMITH, D. et al. DNA sequence based typing of swine leukocyte antigens in Yucatan Miniature Pigs. Xenotransplantation, v.12, n.6, p.481-488, 2005. Available from: <http://onlinelibrary.wiley. com/doi/10.1111/j.1399-3089.2005.00252.x/abstract>. Accessed: Jun. 23, 2016. doi: 10.1111/j.1399-3089.2005.00252.x.
VENTURINI, A. et al. Combined intra-extra-articular technique for stabilisation of coxofemoral luxation. Veterinary and Comparative Orthopaedics and Traumatology, v.23, n.3, p.182185, 2010. Available from: <http://vcot.schattauer.de/en/contents/ archiveestandard/issue/1076/manuscript/12992/show.html. Accessed: Jun. 23, 2016. doi: 10.3415/VCOT-09-08-0087.

VENZIN, C.; MONTAVON, P.M. Augmentation of the transverse acetabular ligament in canine caudoventral hip luxation. Veterinary and Comparative Orthopaedics and Traumatology, v.20, n.4, p.320-323, 2007. Available from: $<$ http://vcot.schattauer.de/en/contents/archiveestandard/ manuscript/9043.html. Accessed: Jun. 23, 2016. doi: 10.1160/ VCOT-06-12-0098. 